\title{
Anlama Becerisi Açısından Okuma ve Dinleme/İzleme Stratejilerinin Türkçe Ders Kitaplarındaki Yeri
}

\author{
DOI: $10.26466 /$ opus. 814783
}

\author{
Bora Bayram* ${ }^{*}$ Elif Aktaş ** \\ * Dr. Öğr. Üyesi, Alanya Alaaddin Keykubat Üniversitesi, Eğitim Fakültesi, Türkçe Eğitimi Ana \\ Bilim Dalı, Alanya/Türkiye \\ E-Posta: bora.bayram@alanya.edu.tr \\ ORCID: 0000-0002-0693-4651 \\ ** Doç. Dr., Alanya Alaaddin Keykubat Üniversitesi, Eğitim Fakültesi, Türkçe Eğitimi Ana Bilim \\ Dalı, Alanya/Türkiye \\ E-Posta: elif.aktas@alanya.edu.tr \\ ORCID: $\underline{0000-0001-5573-2274}$
}

\section{Öz}

Türkçe öğretimi; temel olarak bireyin dinleme, okuma, konuşma ve yazma olmak üzere dört temel dil becerisini geliştirmeyi amaçlamaktadır. Anlama ve anlatma becerileri olarak sinflandırılan bu öğrenme alanlarının geliştirilmesi için birtakım stratejilerin etkin olarak kullanılması gereklidir. Bu çalışmada 2019 Türkçe Dersi Öğretim Programı'na (TDÖP) göre hazırlanan Türkçe ders kitaplarında yer alan dinlemelizleme ve okuma stratejilerinin sinıf düzeyi, metin türü ve ders kitaplarına göre dağılımın tespit etmek amaçlanmıştır. Buna göre TDÖP'de hangi okuma ve dinleme stratejilerine yer verildiği ve bu okuma ve dinleme stratejilerinin Türkçe ders kitaplarında ne denli yer aldığ tespit edilmiştir. Nitel araştırma yöntemiyle desenlenen çalışmada doküman inceleme yöntemi kullanılmıştır. Araştırmanın inceleme nesnelerini 2019-2020 eğitim-öğretim yılında okutulan on dört adet 1-8. sinıf Türkçe ders kitabı oluşturmaktadır. Verilerin analizinde betimsel analiz tekniklerinden frekans ve yüzde analizi kullanılmıştır. Araştırmanın sonuçlarına göre TDÖP'de okuma ve dinleme/izleme stratejilerine ders kitaplarında dengeli bir şekilde yer verilmediği tespit edilmiştir. Araştırma sonuçlarına göre gerek ders kitabı yazarlarının gerekse de dersin uygulanması sürecinde öğretmenlerin anlama becerisini geliştirmeye yönelik aynı astratejileri kullanma konusunda ısrarcı olmak yerine farklı stratejileri işe koşmaları önerilebilir.

Anahtar Kelimeler: Anlama becerileri, okuma stratejileri, dinlemelizleme stratejileri, Türkçe Öğretim Programi. 


\title{
Reading and Listening/Viewing Strategies in Terms of Comprehension Skills in Turkish Language Textbooks
}

\begin{abstract}
Turkish language teaching aims to develop four basic language skills (listening, reading, speaking and writing) of the individual. Some strategies need to be used effectively to develop these learning areas, which are classified as comprehension and narrative skills. In this study, it was aimed to determine the distribution of listening / viewing and reading strategies in Turkish language textbooks prepared according to the 2019 Turkish Language Lesson Curriculum (TLLC) in terms of grade level, text type and textbooks. Accordingly, it was determined which reading and listening strategies are included in TLLC and how much of these mentioned reading and listening strategies are included in Turkish language textbooks. Document analysis method was used in the study designed with qualitative research method. The data collection of the study consists of sixteen 1st-8th grade Turkish textbooks taught in the 20192020 academic year. Frequency and percentage analysis, one of the descriptive analysis techniques, were used to analyze the data. According to the results of the research, it was determined that reading and listening strategies are distributed in a dispersed way and these strategies are not used in textbooks in a sufficient and balanced way in TLLC. According to the results of the research, it may be suggested that both the textbook writers and the teachers should use different strategies instead of insisting on using the same astrategies to improve their comprehension skills during the implementation of the course.
\end{abstract}

Keywords: Comprehension skills, reading strategies, listening/ viewing strategies, Turkish Educational Program. 


\section{Giriş}

Türkçe öğretimi, temel eğitimden yükseköğretime kadar bireyin anlama (dinleme/izleme ve okuma) ile anlatma (konuşma ve yazma) becerilerini geliştirmeyi amaçlamaktadır. Bu doğrultuda önemli bir kılavuz olan 2019 Türkçe Dersi Öğretim Programı (TDÖP), öğrencilerin hayat boyu kullanabilecekleri dört temel dil becerilerisini ve zihinsel becerileri kazanmalarını sağlayacak şekilde yapılandırılmıştır. Programda bu dil ve zihinsel becerilerin gelişmesi, diğer tüm alanlarda öğrenmenin, kişisel ve sosyal gelişimin ön şartı olarak kabul görmektedir (MEB, 2019, s.25).

Anlama becerilerinden biri olan okuma, öğrencinin bilişsel gelişimine en fazla katkı sağlayan öğrenme alanlarından biridir. Okuma; görme, algılama, seslendirme, anlama, zihinde yapılandırma gibi göz, ses, söz ve beynin çeşitli işlevlerinden oluşan karmaşık bir süreçtir (MEB, 2005, s.16). Öğrencilerin okuma becerisi edinip okuma zevk ve alışkanlığı kazanmaları, ilköğretimin genel amaçlarındandır. Okuma kapsamında çok çeşitli okuma metinleri ile karşılaşmak mümkündür. Öğrenme-öğretme sürecinde okuma çalışmalarından önce amaç ve uygun bir strateji belirlemek, öğrencilerin okuduğunu anlama becerisinin gelişiminde, okuma motivasyonunun artmasında, derse karşı ilgilerinin çekilmesinde ve okuma alışkanlığı kazanmalarında oldukça önemlidir. Bu nedenle öğretmenler, okuma etkinliklerinden önce mutlaka strateji belirleme işlemini gerçekleştirmelidirler.

Anlama becerilerinin bir diğer bileşeni ise dinlemedir. İletişim sürecinin temel ögelerinden biri olan dinleme, işitilen sesleri anlamlandırma ve bu anlamlandırma sonucunda bir tepkide bulunma (Melanlığlu, 2013) olarak tanımlanmaktadır. Dinleme, seslerin anlamlandırılarak zihinde yapılandırıldığı karmaşık bir süreçtir (MEB, 2005, s.13). İşitme ve dinleme birbirinden farklı eylemlerdir. Nitekim dinleme, aynı zamanda bir anlama becerisidir. Oysa işitme, etraftaki sesleri anlamlandırma ve yorumlama çabasına girmeden yalnızca duyma faaliyeti olarak tanımlanabilir. Ergin (2014, ss. 107-113) işitmenin fizyolojik, dinlemenin ise psikolojik bir süreç olduğunu; işitmenin kulakla dinlemenin de zihinle yapıldığını vurgulamaktadır. Sağlık problemi olmayan her insan etraftaki sesleri algilar fakat bu sesleri anlanma ve yorumlama çabası üst düzey bir beceri gerektirir. İşitilen bir sesten anlam çlkarma, konu hakkında sorular sorabilme, konunun bütününü kavrayabilme, mantık yürütme ise dinleme faaliyetidir. Aktaş ve Gündüz'e (2004, s. 247) göre 
işitme, kişinin iradesi dışında gerçekleşirken dinleme, amaca yönelik olarak öğrenilecek bir beceridir. Bununla birlikte işitme, dinlemenin ön koşuludur. İşitme olmadan dinleme olmaz.

Dinleme/izleme, Türkçenin temel dil becerilerinden biri olup anne karnında edinilmeye başlamaktadır. Nitekim çocukların dil öğrenme süreci dinleyerek başlamaktadır. Dinleme, diğer öğrenme alanlarına temel oluşturmaktadır. Öğrenme sürecini dinleme becerisiyle destekleyen öğrenciler, bu becerilerini hayatı boyunca bir öğrenme vasıtası olarak kullanabilirler. Bundan dolayı dinleme becerilerinin erken yaşlarda öğretilmesi gerekmektedir. Dinleme becerisini geliştirmek için yapılacak çalışmalardan biri de dinleme amacina uygun yöntem belirlemedir (MEB, 2005, s.14). Dinleme öncesi yöntem/strateji belirlemek; dinlenenlerin kalıcılığını sağlamada, anlama becerisini geliştirmede, motivasyonu sağlamada oldukça önemlidir.

Dinlemenin doğuştan getirilen bir beceri olması, onun yıllarca eğitimde ihmal edilen bir öğrenme alanı olmasına neden olmuştur (Yalçın, 2002, s. 123; Doğan, 2013, s.155). Ayrı bir öğrenme alanı olarak ilk kez 1981 Türkçe Dersi Öğretim Programı́nda yer verilen dinleme becerisi, 2005 ve 2019 programlarında da kazanım ve açıklama boyutunda ayrıntılı olarak yer almıştır.

Tematik anlayış esas alınarak hazırlanan öğretim programında beceri temelli bir yaklaşım söz konusudur. Bu bakımdan TDÖP'de belirlenen hedef ve kazanımların gerçekleştirilmesi için eğitim-öğretim sürecinde kimi etkinliklerin uygulanması gerekmektedir. Nitekim etkinlik temelli uygulamalarla öğrencilerin temel becerilerini gelişitirmek mümkündür. Anlama ve anlatma becerilerini gelişen birey kendini yazılı ve sözlü olarak ifade edebilmekte ve anlama becerisi kazanmaktadır. Bu becerilerin geliştirilmesi için birtakım stratejilerin etkin olarak kullanılması gereklidir.

Literatürde yaklaşım, strateji, yöntem ve teknik kavramlarının sıklıkla birbirinin yerine kullanıldığı görülmektedir. Ancak bu kavramlar arasında fark vardır. Strateji daha genel kapsamlı bir terim olup yöntem ve tekniği içine almaktadır. Strateji; bir amaca ulaşmak üzere işe koşulabilecek yöntem, teknik, araç ve gereçlerin belirlendiği, genel çerçeve niteliğinde bir plandir. Okuma ya da dinleme/izleme yöntemi; okuma/dinleme amacı etrafında şekillenen türe has süreç, teknik ve etkinliklerin işletildiği, uygulmaya dönük, özel bir plan olarak tanımlanabilir. Okuma ya da dinleme/izleme tekniği ise türe ait özel amaçlar doğrultusunda okuma ya da dinlemenin geliştirilmesine hizmet eden çeşitli taktiklerdir (Kurudayığlu, 2020, s. 172). 
Programda, her sinuf düzeyinde okuma ve dinleme/izleme becerileri ile ilgili kazanımlara yer verilmektedir. Bu kazanımlar içinde tüm sınıflarda tekrar eden kazanımlar dikkat çekmektedir: "Okuma stratejilerini uygular.", "Dinleme/izleme stratejilerini uygular." şeklindeki kazanım ifadelerinin tüm sinıflarda tekrar etmesi, anlama becerilerinin geliştirilmesinde birtakım stratejilerin kullanımını da gerekli kılmaktadır. 2019 TDÖP'de yer alan bu stratejilere ilişkin dağılım, Tablo 1 ve 2'de yer almaktadır.

Tablo 1. Türkçe Öğretim Programındaki okuma stratejileri

\begin{tabular}{|c|c|c|c|c|c|c|c|c|}
\hline Okuma Stratejileri & 1. sinif & 2. sinif & 3. sinif & 4. sinif & 5. sinif & 6. sinif & 7. sinif & 8. sinif \\
\hline Sesli okuma & - & $\sqrt{ }$ & $\sqrt{ }$ & $\sqrt{ }$ & $\sqrt{ }$ & $\sqrt{ }$ & - & - \\
\hline Sessiz okuma & - & $\sqrt{ }$ & $\sqrt{ }$ & $\sqrt{ }$ & $\sqrt{ }$ & $\sqrt{ }$ & - & - \\
\hline $\begin{array}{l}\text { Tahmin } \\
\text { ederek okuma }\end{array}$ & - & - & $\sqrt{ }$ & $\sqrt{ }$ & $\sqrt{ }$ & $\sqrt{ }$ & - & - \\
\hline Soru sorarak okuma & - & - & - & $\sqrt{ }$ & $\sqrt{ }$ & $\sqrt{ }$ & - & - \\
\hline Grup hâlinde okuma & - & - & - & - & $\sqrt{ }$ & - & - & - \\
\hline Söz korosu & - & - & - & - & $\sqrt{ }$ & - & - & - \\
\hline Ezberleyerek okuma & - & - & - & - & $\sqrt{ }$ & - & - & - \\
\hline Hizlı okuma & - & - & - & - & $\sqrt{ }$ & $\sqrt{ }$ & - & - \\
\hline Not alarak okuma & - & - & - & - & - & $\sqrt{ }$ & $\sqrt{ }$ & $\sqrt{ }$ \\
\hline Okuma tiyatrosu & - & - & - & - & - & $\sqrt{ }$ & - & - \\
\hline Göz atarak okuma & - & - & - & - & - & - & $\sqrt{ }$ & $\sqrt{ }$ \\
\hline Özetleyerek okuma & - & - & - & - & - & - & $\sqrt{ }$ & $\sqrt{ }$ \\
\hline İşaretleyerek okuma & - & - & - & - & - & - & $\sqrt{ }$ & - \\
\hline Tartışarak okuma & - & - & - & - & - & - & $\sqrt{ }$ & $\sqrt{ }$ \\
\hline Eleştirel okuma & - & - & - & - & - & - & - & $\sqrt{ }$ \\
\hline
\end{tabular}

Tablo 1'e göre TDÖP'da birinci sınıf düzeyinde herhangi bir okuma stratejisine yer verilmemiştir. Sınıf seviyesi ilerledikçe daha çok stratejinin önerilmesi dikkat çekmektedir.

5-8. sinfflarda önerilen okuma stratejilerin sonuna "bunun gibi" ifadesi eklenerek çeşitlilik sağlanmaya çalışıldığı görülmektedir. Bu durum, ders kitabı yazarları ve uygulayıcı konumundaki öğretmenler açısından bir esneklik olarak algılansa da belirsizliğe neden olmaktadır. Dolayısıyla kimi stratejilerin bazı sınıf seviyelerinde hiç kullanılmaması riski ortaya çıkmaktadır. Bunun yerine kazanım veya kazanım açıklamasında açıça yazılması, sınıf seviyeleri bakımından dengeli dağılımının sağlanması önemlidir.

Sesli ve sessiz okuma, bireyin yaşam boyu kullanabileceği iki temel okuma türüdür. Bu iki okuma türüne tüm sınıf düzeylerinde yer verilmesi gerekmektedir. Bununla birlikte özellikle sessiz okumanın sesli okumadan 
daha önce kazanılan bir beceri olduğu düşünülürse sesli okumaya ilk sınıflarda, sessiz okumaya ise sonraki sinıf düzeylerinde daha çok yer verilmesi mantıklıdır. Oysa programda bu açıdan bir hassasiyet gözetilmemiştir. Sessiz okumaya 2. sinıftan itibaren geçilmesi önerilmektedir (Ülper ve Yağmur, 2016). Bu açıdan programda sesli okuma türüne 2. sinıftan itibaren yer verilmesi uygundur. Bireyin kısa bir zaman diliminde çok daha fazla kelime okuması anlamına gelen hızlı okuma becerisi ise doğuştan getirilen bir yetenek değildir. Sadece kelimelerin hılı okunması değil aynı zamanda okunan metnin ana hatlarıyla anlaşılması da demek olan hızlı okuma, bazı özel teknik ve becerileri bünyesinde bulunduran bir eğitim sonrası kazanılmaktadır. Programda bu okuma türüne yalnızca 5 ve 6 . sinıf düzeyinde yer verilmesi dikkat çekmektedir. Ayrıca bu okuma türünü henüz okuma alışkanlığı kazanma aşamasında olan ilköğretim öğrencileri tarafından bilinmesinin gerekliliği tartışılabilir. Aynı şekilde öğretmenlerin de bu konuda bir yeterliliğe sahip olup olmadığ tartışmalı bir durumdur. Tablo 1 incelendiğinde ezberleyerek okumanın yalnızca 5. sınıf düzeyinde, ayrıca hikâye edici metinleri canlandırarak okuma anlamına gelen okuma tiyatrosunun yalnızca 6 . sınıfta yer aldığ1 görülmektedir.

Tablo 2. Türkçe Öğretim Programındaki dinleme/izleme stratejileri

\begin{tabular}{llllllllll}
\hline $\begin{array}{l}\text { Dinleme/İleme } \\
\text { Stratejileri }\end{array}$ & 1. sinif & 2. sinıf & 3. sinif & 4. sinif & 5. sinıf & 6. sinıf & 7. sinif & 8. sinıf \\
\hline Not alarak dinleme & - & - & - & $\sqrt{ }$ & $\sqrt{ }$ & $\sqrt{ }$ & $\sqrt{ }$ & $\sqrt{ }$ \\
\hline Katılımlı dinleme & - & - & - & - & $\sqrt{ }$ & $\sqrt{ }$ & $\sqrt{ }$ & - \\
\hline $\begin{array}{l}\text { Grup hâlinde } \\
\text { dinleme }\end{array}$ & - & - & - & - & $\sqrt{ }$ & $\sqrt{ }$ & - & - \\
\hline Katılımsız dinleme & - & - & - & - & - & $\sqrt{ }$ & $\sqrt{ }$ & - \\
\hline Empati kurarak & - & - & - & -- & - & - & $\sqrt{ }$ & $\sqrt{ }$ \\
\hline Seçici dinleme & - & - & - & - & - & - & - & $\sqrt{ }$ \\
\hline Yaratıcı dinleme & - & - & - & - & - & - & - & $\sqrt{ }$ \\
\hline Eleştirel dinleme & - & - & - & - & - & - & - & $\sqrt{ }$ \\
\hline
\end{tabular}

Tablo 2'ye göre TDÖP'de 1, 2 ve 3. sinıf düzeyinde herhangi bir dinleme/izleme stratejisine yer verilmemiştir. Dinleme/izleme stratejileri ilk üç sinıf düzeyinde okuma stratejilerinde olduğu gibi nezaket kuralları ve dikkat yoğunlaştırma kapsamında değerlendirilmiştir. Yine 5-8. Sınıf seviyelerinde okuma stratejilerinde olduğu gibi dinleme /izleme stratejilerinde de "bunun gibi" ifadesiyle çeşitlilik sağlanmaya çalışılmıştır. Tabloda ayrıca yaratıcı ve eleştirel dinlemeye yalnızca 8 . sınıf düzeyinde yer verildiği görülmektedir. 
Oysa TDÖP’nin genel amaçları ve temel becerilerinden biri de öğrencilerin yaratıcı ve eleştirel düşünme becerilerini geliştirmektir. Bu, yaratıcı ve eleştirel dinleme türlerine tüm sınıf düzeylerinde yer verilmesi gerekliliğini doğurmaktadır.

Öğretim programlarında yer alan kazanımlar, öğrencilere öğretim ortamlarında birtakım etkinlikler yoluyla kazandırılmaktadır. Öğrenme-öğretme sürecindeki bu etkinlikler ya öğretmen tarafından önceden hazırlanır ya da ders kitaplarında hazır olarak yer alır. Ancak genellikle öğretmenler, öğrenme-öğretme sürecinde ders kitaplarındaki etkinlikleri uygulamaktadırlar. 2005'ten beri, hazırlanan Türkçe öğretim programlarında beceri temelli bir anlayış esas alınmıştır. Çer'e (2016) göre Türkçe öğretimindeki dil becerileri bütüncül bir anlayışla ve etkinlik temelli uygulamalarla kazandırılmalıdır. Okulda alınan eğitimde öğrencilerin etkin öğrenen bireyler olarak yetiştirilmesinde, kendilerini sözlü ve yazılı olarak ifade edebilmelerinde, yaratıcılıklarının geliştirilmesinde etkinliklerin önemi yadsınamaz. Bu bağlamda ders kitaplarındaki etkinliklerin niteliği, kapsamı ve etkililiğini tespit eden çalışmalar önemlidir. Türkiye' de ders kitapları üzerine pek çok çalışma yapılmıştır. Ancak ders kitaplarındaki okuma ve dinleme/izleme stratejilerinin yayınevlerine, sınıf düzeylerine ve metin türlerine göre dağılımını ayrıntılı olarak inceleyen çalışmalar kısıtlıdır.

$\mathrm{Bu}$ araştırmanın amacı, beceri temelli bir anlayışa dayanan 2019 Türkçe Dersi Öğretim Programı́na göre hazırlanan 1-8. sınıf Türkçe ders kitaplarındaki okuma ile dinleme/izleme stratejilerinin sınıf düzeyi, metin türleri ve yayınevlerine göre dağılımının belirlenmesidir. Araştırma kapsamında aşağıdaki sorulara yanıt aranmıştır:

1. 1-8. sınıf Türkçe ders kitaplarındaki okuma stratejilerinin sınıf düzeylerine göre dağılımı nedir?

2. 1-8. sınıf Türkçe ders kitaplarındaki okuma stratejilerinin metin türü bakımından yayınevlerine göre dağılımı nedir?

3. 1-8. sınıf Türkçe ders kitaplarındaki dinleme/izleme stratejilerinin s1nıf düzeylerine göre dağılımı nedir?

4. 1-8. sınıf Türkçe ders kitaplarındaki dinleme/izleme stratejilerinin metin türü bakımından yayınevlerine göre dağılımı nedir? 


\section{Yöntem}

Türkçe ders kitaplarındaki okuma ile dinleme/izleme stratejilerinin sınıf düzeylerine, metin türlerine ve yayınevlerine göre dağılımını belirlemeyi amaçlayan bu çalışmada, nitel araştırma yöntemi kullanılmıştır. Nitel araştırmalarda gözlem, görüşme ve doküman analizi gibi nitel veri toplama yöntemlerinin kullanılır ve olaylar doğal ortamında gerçekçi bir biçimde ortaya konur (Yıldırım ve Şimşek, 2016). Çalışmanın verileri, nitel veri toplama araçlarından doküman incelemesiyle elde edilmiştir. Doküman incelemesi, araştırılmak istenen olgu ve olgular hakkında bilgi içeren yazılı, görsel ve işitsel verilerin analiz edilmesini anlamına gelir (Yıldırım ve Şimşek, 2016).

\section{Araştırmanın İnceleme Nesneleri ve Veri Toplama Aracı}

Araştırmada Millî Eğitim Bakanlığı ve özel yayınevlerine ait 14 Türkçe ders kitabı (1-8. sınıflar) doküman olarak incelenmiştir. MEB yayınlarına ait 2. sınıf Türkçe kitabıyla özel yayınevine ait 8. sınıf Türkçe ders kitabının baskısı bulunmadığı için bu iki gruba ilişkin inceleme yapılamamış, tablolarda bu bölümler boş bırakılmıştır. Bu doğrultuda, incelemeye konu ders kitaplarındaki etkinliklerde kullanılan okuma ve dinleme/izleme stratejileri tespit edilip s1nıflandırılmıştır. Verilerin sınıflandırılmasında kullanılan form ise 2005 ve 2019 Türkçe öğretim programlarında yer alan okuma ve dinleme/izleme stratejilerinin tespit edilmesiyle ve ilgili literatürün taranmasıyla oluşturulmuştur. Araştırmanın inceleme nesnesi durumundaki Türkçe ders kitaplarının künyeleri Tablo 3'te gösterilmiştir.

Tablo 3. Araştırmanın inceleme nesnesi olan ders kitaplarn

\begin{tabular}{|c|c|c|c|}
\hline $\begin{array}{l}\text { Sinıf } \\
\text { Seviyesi }\end{array}$ & Yayınevi & Yazarlar & Editör \\
\hline \multirow[t]{2}{*}{ 1.sinif } & Cem Web Ofset & $\begin{array}{l}\text { E. Aksoy, G. C. Hamurcu, A. Akkuş, } \\
\text { S. Ziya }\end{array}$ & - \\
\hline & MEB Yayınları & D. Civelek, D. Y. Gündüz, F. Karafilik & - \\
\hline 2.sinif & Koza Yayınları & A. Ataşçi & B. Taş \\
\hline \multirow[t]{2}{*}{ 3.sinif } & Sonuç Yayınları & E. Ş. Dağlıŏglu & - \\
\hline & MEB Yayınları & $\begin{array}{l}\text { B. E. Karaduman, } \\
\text { E. Özdemir, O. Y1lmaz }\end{array}$ & O. Yilmaz \\
\hline \multirow[t]{2}{*}{ 4.sinif } & Koza Yayınları & A. Ataşçi & - \\
\hline & MEB Yayınları & H. K. Ayan, Ü. Arslan, S. Kul, N. Yılmaz & - \\
\hline \multirow[t]{2}{*}{ 5. sinif } & Anittepe Yayınları & Ş. Ç. Baran, E. Diren & - \\
\hline & MEB Yayınları & $\begin{array}{l}\text { H. A. Haykır, H. Kaplan, A. Kıryar, } \\
\text { R. Tarakçı, E. Üstün }\end{array}$ & $\begin{array}{l}\text { E. Aktaş, } \\
\text { B. Bayram }\end{array}$ \\
\hline
\end{tabular}




\begin{tabular}{llll}
\hline 6. Sınıf & Ekoyay & T. Demirel & - \\
\cline { 2 - 4 } & MEB Yayınları & $\begin{array}{l}\text { S. Ceylan, K. Duru, G. Erkek, M. Pastut- } \\
\text { maz }\end{array}$ & $\begin{array}{l}\text { Z. Batur, S. } \\
\text { Ceylan }\end{array}$ \\
\hline 7. sınıf & Özgün Yayıncılık & T. Kır, E. Kırman, S. Yağız & E. Kırman \\
\cline { 2 - 4 } & MEB Yayınları & $\begin{array}{l}\text { A. Akgül, N. Demirer, E. Gürcan, D. Kar- } \\
\text { adaş, İ. Karahan, A. Uysal }\end{array}$ & N. Demirer \\
\hline 8.sınıf & MEB Yayınları & H. Eselioğlu, S. Sert A. Yücel & A. Yücel \\
\hline
\end{tabular}

\section{Verilerin Analizi}

Araştırmanın sonucunda elde edilen veriler, betimsel analizle çözümlenmiştir. Betimsel analizde okuyucunun ham verileri, ihtiyaç duyduğunda kullanmak üzere anlayabileceği bir şekle dönüştürmesi söz konusudur. Betimsel çözümlemede elde edilen veriler, önceden belirlenen temalara göre özetlenip yorumlanır (Yıldırım ve Şimşek, 2016). Bu araştırmada da veriler, betimleyici analiz tekniklerinden yüzde ve frekans analizi ile çözümlenmiştir. Öncelikle Türkçe ders kitaplarındaki okuma ve dinleme etkinliklerine yönelik stratejiler tespit edilmiş; sonra yayınevi, metin türü ve sınıf düzeyine göre sınıflandırılmıştır. Son olarak da frekans ve yüzde değerleri ile sayısal veriler tablolaştırılmıştır.

Geçerlik ve Güvenirlik: Bu araştırmada elde edilen verilerin güvenirliğini sağlamak üzere iki veya daha fazla araştırmacının birbirlerinden bağımsız olarak analiz ettiği nitel bulguların karşılaştırılması olarak tanımlanan araştırmacı üçgenlemesi kullanılmıştır (Merriam, 2013; Patton, 2014). Bu kapsamda tanımlanan bulgular, iki araştırmacı tarafından incelenmiştir. İki araştırmacı tarafından bağımsız olarak analiz edilerek ulaşılan sonuçlar Miles ve Huberman'ın (1994) güvenirlik formülü ile hesaplanmıştır. \%98 çkan uyuşum değeriyle araştırmanın güvenilir olduğu görülmüştür. Farklılık gösteren veriler yeniden gözden geçirilip tartışılarak ortak bir uzlaşıya varılmıştır. $\mathrm{Bu}$ şekilde tüm veriler üzerinde uzlaşma sağlanmıştır. Araştırmanın süreci detaylı olarak yer verilerek çalışmanın güvenirliğini desteklediği düşünülmektedir. Ayıca araştırmada elde edilen bulguların ve sonuçların gerçeği yansıtması açısından, verilerden doğrudan alıntılar yapılarak araştırmanın iç geçerliğini desteklediği düşünülmektedir. 


\section{Bulgular}

Bu bölümde okuma ve dinleme izleme stratejilerinin sinff seviyelerine ve yayınevlerine göre dağılımına ilişkin elde edilen bulgular tablolaştırılarak sunulmuştur.

Tablo 3. Okuma stratejilerinin sını seviyeleri bakımından yayınevlerine göre dağılımı

\begin{tabular}{|c|c|c|c|c|c|c|c|c|c|c|c|c|c|c|c|c|c|c|c|}
\hline \multirow{2}{*}{$\begin{array}{l}\text { Okuma } \\
\text { Stratejileri }\end{array}$} & \multirow{2}{*}{$\begin{array}{c}\mathrm{f} / \\
\% \\
\end{array}$} & \multicolumn{9}{|c|}{ MEB Yayınları Sınıflar } & \multicolumn{9}{|c|}{ Özel Yayınevi Sınıflar } \\
\hline & & 1 & 2 & 3 & 4 & 5 & 6 & 7 & 8 & $T$ & 1 & 2 & 3 & 4 & 5 & 6 & 7 & 8 & $T$ \\
\hline \multirow{2}{*}{ Eleştirel okuma } & $\mathrm{f}$ & & & & & 1 & & 1 & 1 & 3 & & & & & 1 & & & & 1 \\
\hline & $\%$ & & & & & 3 & & 3 & 3 & 2 & & & & & 2,5 & & & & 0,4 \\
\hline \multirow{2}{*}{ Yaratic okuma } & $\mathrm{f}$ & & & & & & & & & & & & & & & & & & \\
\hline & $\%$ & & & & & & & & & & & & & & & & & & \\
\hline \multirow{2}{*}{$\begin{array}{l}\text { Altını } \\
\text { çizerek okuma }\end{array}$} & $\mathrm{f}$ & & & & 1 & 1 & 2 & 3 & 1 & 8 & & & & 2 & 1 & & 2 & & 5 \\
\hline & $\%$ & & & & 4 & 3 & 7 & 9 & 3 & 4 & & & & 5 & 2,5 & & 8 & & 2 \\
\hline \multirow{2}{*}{$\begin{array}{l}\text { Göz } \\
\text { atarak okuma }\end{array}$} & $\mathrm{f}$ & & & & & & & & & & & & & & & & & & \\
\hline & $\%$ & & & & & & & & & & & & & & & & & & \\
\hline \multirow{2}{*}{$\begin{array}{l}\text { Soru } \\
\text { sorarak okuma }\end{array}$} & $\mathrm{f}$ & & & & & & & & & & & & & & 1 & 3 & & & 4 \\
\hline & $\%$ & & & & & & & & & & & & & & 2,5 & 7 & & & 2 \\
\hline \multirow{2}{*}{$\begin{array}{l}\text { Özetleyerek } \\
\text { okuma }\end{array}$} & $\mathrm{f}$ & & & & & & 2 & & & 2 & & & & & & & & & \\
\hline & $\%$ & & & & & & 7 & & & 1 & & & & & & & & & \\
\hline \multirow{2}{*}{$\begin{array}{l}\text { İşaretleyerek } \\
\text { okuma }\end{array}$} & $\mathrm{f}$ & & & & & & & 1 & & 1 & & & & & 1 & & 1 & & 2 \\
\hline & $\%$ & & & & & & & 3 & & 1 & & & & & 2,5 & & 4 & & 1 \\
\hline \multirow{2}{*}{ Sesli okuma } & $\mathrm{f}$ & & & 16 & & 17 & 22 & 11 & 10 & 76 & & 14 & 16 & 15 & 10 & 15 & 12 & & 82 \\
\hline & $\%$ & & & 64 & & 57 & 73 & 34 & 32 & 40 & & 50 & 50 & 38 & 26 & 37 & 50 & & 38 \\
\hline \multirow{2}{*}{ Sessiz okuma } & $\mathrm{f}$ & & & 6 & & 3 & & 6 & & 15 & & 3 & 4 & 10 & 7 & 5 & 5 & & 34 \\
\hline & $\%$ & & & 24 & & 10 & & 19 & & 8 & & 11 & 13 & 25 & 18 & 12 & 21 & & 16 \\
\hline \multirow{2}{*}{$\begin{array}{l}\text { Tahmin } \\
\text { ederek okuma }\end{array}$} & $\mathrm{f}$ & 2 & & 2 & 4 & 2 & 1 & & 3 & 14 & & 3 & 6 & 4 & 6 & 3 & 1 & & 23 \\
\hline & $\%$ & 15 & & 8 & 15 & 7 & 3 & & 10 & 7 & & 11 & 19 & 10 & 15 & 7 & 4 & & 11 \\
\hline \multirow{2}{*}{ Ezberleme } & $\mathrm{f}$ & & & & & & & 1 & & 1 & & 1 & & & 1 & & & & 2 \\
\hline & $\%$ & & & & & & & 3 & & 1 & & 3,5 & & & 2,5 & & & & 1 \\
\hline \multirow{2}{*}{ Okuma tiyatrosu } & $\mathrm{f}$ & & & & & 1 & 1 & & & 2 & & 1 & 1 & 1 & 4 & 2 & & & 9 \\
\hline & $\%$ & & & & & 3 & 3 & & & 1 & & 3,5 & 3 & 2 & 10 & 5 & & & 4 \\
\hline Tartışarak & $\mathrm{f}$ & & & & & & & & & & & & & 2 & & & & & 2 \\
\hline okuma & $\%$ & & & & & & & & & & & & & 5 & & & & & 1 \\
\hline Hyzlı okuma & $\mathrm{f}$ & & & & & & & & & & & & & & & 1 & & & 1 \\
\hline Hizli okuma & $\%$ & & & & & & & & & & & & & & & 2,4 & & & 0,4 \\
\hline Paylaşarak & $\mathrm{f}$ & & & & & & & & & & & 1 & & 1 & 1 & & & & 3 \\
\hline okuma & $\%$ & & & & & & & & & & & 3,5 & & 2 & 2,5 & & & & 1 \\
\hline Not & $\mathrm{f}$ & & & & & & & 3 & 4 & 7 & & & 1 & & 3 & 1 & 2 & & 7 \\
\hline alarak okuma & $\%$ & & & & & & & 9 & 13 & 4 & & & 3 & & 8 & 2,4 & 8 & & 3 \\
\hline & $\mathrm{f}$ & 1 & & 1 & 2 & 3 & 1 & 3 & 4 & 15 & & & 4 & 2 & 1 & & & & 7 \\
\hline Görsel okuma & $\%$ & 8 & & 4 & 7 & 10 & 3 & 9 & 13 & 8 & & & 12 & 5 & 2,5 & & & & 3 \\
\hline S̈̈zkorosu & $\mathrm{f}$ & & & & & & & 1 & & 1 & & & & & & 1 & & & 1 \\
\hline soz korosu & $\%$ & & & & & & & 3 & & 1 & & & & & & 2,4 & & & 0,4 \\
\hline & $\mathrm{f}$ & & & & 4 & 1 & & 1 & & 6 & & 1 & & 1 & 1 & 10 & & & 13 \\
\hline Seçici okuma & $\%$ & & & & 15 & 3 & & 3 & & 3 & & 3,5 & & 2 & 2,5 & 24 & & & 6 \\
\hline Yankllayıcı & $\mathrm{f}$ & & & & & 1 & & & & 1 & & & & & & & & & - \\
\hline okuma & $\%$ & & & & & 3 & & & & 1 & & & & & & & & & - \\
\hline & $\mathrm{f}$ & 10 & & & 16 & & 1 & 1 & 8 & 36 & 12 & 4 & & 2 & 1 & & 1 & & 20 \\
\hline Belirtilmemiş & $\%$ & 77 & & & 59 & & 3 & 3 & 26 & 19 & 100 & 14 & & 5 & 2,5 & & 4 & & 9 \\
\hline Toplam & $\mathrm{f}$ & 13 & & 25 & 27 & 30 & 30 & 32 & 31 & 188 & 12 & 28 & 32 & 40 & 39 & 41 & 24 & & 216 \\
\hline Ioplam & $\%$ & 7 & & 13 & 14 & 16 & 16 & 17 & 16 & 100 & 6 & 13 & 15 & 18 & 18 & 18 & 11 & & 100 \\
\hline
\end{tabular}


Tablo3'e göre MEB tarafından basılmış Türkçe ders kitaplarında 188, özel yayınevleri tarafından basılmış Türkçe ders kitaplarında 216 okuma stratejisinin kullanıldığ 1 belirlenmiştir.

7. sınıf ders kitabıdır ( $\mathrm{f}=32)$, MEB kitapları içerisinde okuma stratejisine en fazla yer verilen ders kitabıdır. Bunu 8. sinıf $(\mathrm{f}=31), 6$. sinıf $(\mathrm{f}=30)$ ve 5 . sinıf $(\mathrm{f}=30)$ ders kitapları takip etmektedir. Özel yayınevleri arasında okuma stratejisine en fazla yer veren ders kitabıysa 6. sinıf ders kitabıdır ( $\mathrm{f}=41)$. Bunu sirasiyla 4 . sinif $(\mathrm{f}=40)$ ve 5 . sinif ders kitapları $(\mathrm{f}=39)$ izlemektedir. Her iki yayınevine ait ders kitaplarının da okuma stratejisine yer verme durumu, küçük istisnalar dışında sınıf seviyesine göre düzenli bir artış göstermektedir. Bunun sebebi 2019 Türkçe Öğretim Programı'nda bahsedilen okuma stratejilerinin fazla olmasıdır. Özel yayınevlerinin hazırladığı Türkçe ders kitaplarında kullanılan toplam okuma stratejilerinin sayısı fazla olsa da gerek MEB gerekse de özel yayınevlerine ait Türkçe ders kitaplarında kullanılan stratejiler oranlar açısından oldukça benzerdir. Bu durum, Türkçe Dersi Öğretim Programı́nda sinıf düzeyine göre kullanılması gereken stratejilerin ders kitabı yazarlarınca dikkate alınmasıyla açıklanabilir.

MEB yayınlarına ait ders kitapları içinde en fazla kullanılan okuma stratejisi sesli okumadır (\%40). Bunu sirasıyla sessiz okuma (\%8), görsel okuma (\%8), tahmin ederek okuma (\%7), altın çizerek okuma (\%4), not alarak okuma (\%4) ve seçici okuma (\%3) izlemektedir. Ayrıca toplamda 36 adet okuma etkinliğinde, okuma stratejisi bulunmamaktadır. Bu bağlamda 1. sınıf okuma metinlerinin $\% 77^{\prime}$ sinde, 4 . sinif okuma metinlerinin $\% 59^{\prime}$ unda ve 8 . sınıf okuma metinlerinin \%26'sında okuma stratejisi belirtilmemiştir. Özel yayınevlerine ait Türkçe ders kitapları içinde en çok kullanılan okuma stratejisi sesli okumadır (\%38). Ardından sesiz okuma (\%16), tahmin ederek okuma (\%11), seçici okuma (\%6), okuma tiyatrosu (\%4), not alarak okuma (\%3) ve görsel okuma gelmektedir. Ayrıca toplamda 20 tane okuma etkinliğinde okuma stratejisi ifade edilmemiştir. Buna göre 1. sınıf ders kitabındaki okuma metinlerinin hiçbirinde, 2 . sınıf okuma metinlerinin ise \%14'ünde okuma stratejisi belirtilmemiştir. Okuma stratejilerine yer verilmemesinin sebebi, öğrencilerin okumayı yeni öğrenmiş olmaları ve alışkanlık hâline getirememiş olmalarıyla ilişkilendirilebilir. Hem MEB kitapları hem de özel yayınevlerine ait ders kitaplarında sesli okuma ve sessiz okuma en sik kullanılan okuma stratejileri olarak göze çarpmaktadır. Bu durumun sesli ve sessiz 
okuma stratejilerinin hayat boyu kullanılan stratejiler olmasıyla ilgili olduğu söylenebilir.

MEB yayınevine ait Türkçe ders kitaplarında sınıf seviyeleri açısından en sık başvurulan okuma stratejilerine bakıldığında sesli okuma stratejisinin en çok 6. sınıf (\%73), 3. sınıf (\%64), 5. sınıf (\%57); sessiz okuma stratejisinin en çok 3. sınıf (\%24), 7. sınıf (\%19), 5. sınıf (\%10); görsel okuma stratejisinin en çok 8. sinıf (\%13), 5. sinıf (\%10) ve 7. sinıf (\%9); tahmin ederek okuma stratejisininse en çok 4. sınıf (\%15), 1. sınıf (\%15) ve 8. sınıf (\%10) ders kitaplarında kullanıldı̆̆ı görülmektedir. Özel yayınevleri tarafından hazırlanmış Türkçe ders kitaplarında en çok başvurulan okuma stratejilerine sınıf bazında bakıldığında sesli okuma stratejisinin \%50 oranıla en çok 2, 3, ve 7. sinıf; sessiz okuma stratejisinin en çok 4. sinıf (\%25), 7. sınıf (\%21), 5. sinıf (\%18); tahmin ederek okuma stratejisininse en çok 3. sınıf (\%19), 5. sinıf (\%15) ve 2. sinıf (\%11) ders kitaplarında kullanıldı ̆̆ göze çarpmaktadır.

Tablo 3'e göre MEB yayınevine ait Türkçe ders kitaplarında yaratıcı okuma, göz atarak okuma, soru sorarak okuma, tartışarak okuma, hızlı okuma, paylaşarak okuma gibi okuma stratejileri kullanılmamıştır. Aynı şekilde özel yayınevlerine ait Türkçe ders kitaplarındaysa yaratıcı okuma, göz atarak okuma, özetleyerek okuma, yankılayıcı okuma stratejilerine yer verilmemiştir. Bu durum, okuma stratejilerinin okuma amacına ve metin türüne göre değişiklik gösterebileceği düşünüldüğünde normal karşılanabilir. Her iki yayınevinde de yaratıcı okuma stratejisine yer verilmemesi, yaratıcı düşünme becerisini gerçekleştirmeyi temel hedef edinen öğretim programının çıktılarıyla örtüşmemektedir. Bu durumun kitap yazarlarının inisiyatifine bırakılmasından dolayı etkinlik olarak ders kitaplarına yansımamasından kaynaklandığı düşünülmektedir.

Kullanılan okuma stratejilerinin çeşitliliği açısından MEB yayınevine ait kitaplar içerisinde 7. sinıf $(\mathrm{f}=10), 5$. sinıf $(\mathrm{f}=9), 8$. sinıf $(\mathrm{f}=6)$; özel yayınevlerine ait ders kitapları arasindaysa 5. sinıf $(f=13), 6$. sinif $(f=9), 4$. sinif $(f=9)$ ders kitapları öne çıkmaktadır. Kullanılan okuma stratejileri bakımından daha az çeşitliliğe sahip olan kitaplar hem MEB yayınevinde hem de özel yayınevlerinde 1. sınıf Türkçe ders kitapları olmuştur. Bu bağlamda MEB yayınevine ait kitapta yer alan okuma stratejisi $(f=2)^{\prime}$ dir. Özel yayınevine ait 1 . sinuf ders kitabındaysa hiçbir okuma stratejisine yer verilmemiştir. 
Tablo 4. Dinleme/izleme stratejilerinin sınf seviyeleri bakımından yayınevlerine göre

\begin{tabular}{|c|c|c|c|c|c|c|c|c|c|c|c|c|c|c|c|c|c|c|c|}
\hline \multirow{2}{*}{$\begin{array}{l}\text { Dinleme } \\
\text { Stratejileri }\end{array}$} & \multirow{2}{*}{$\begin{array}{l}\text { f/ } \\
\%\end{array}$} & \multicolumn{9}{|c|}{$\begin{array}{l}\text { MEB Yayınları } \\
\text { Sinıflar }\end{array}$} & \multicolumn{9}{|c|}{$\begin{array}{l}\text { Özel Yayınevi } \\
\text { Sınıflar }\end{array}$} \\
\hline & & 1 & 2 & 3 & 4 & 5 & 6 & 7 & 8 & $T$ & 1 & 2 & 3 & 4 & 5 & 6 & 7 & 8 & $T$ \\
\hline \multirow{2}{*}{$\begin{array}{l}\text { Katilımlı } \\
\text { dinleme }\end{array}$} & $\mathrm{f}$ & & & & 1 & & & & 1 & 2 & & & & & & & & & - \\
\hline & $\%$ & & & & 7 & & & & 11 & 3 & & & & & & & & & - \\
\hline \multirow{2}{*}{$\begin{array}{l}\text { Kattlimsiz } \\
\text { dinleme }\end{array}$} & $\mathrm{f}$ & & & & & & & & & - & & & & & & & & & - \\
\hline & $\%$ & & & & & & & & & - & & & & & & & & & - \\
\hline \multirow{2}{*}{$\begin{array}{l}\text { Not alarak } \\
\text { dinleme }\end{array}$} & $\mathrm{f}$ & & & & 4 & 4 & 3 & 5 & 3 & 19 & & & & 1 & 3 & 3 & 5 & & 12 \\
\hline & $\%$ & & & & 29 & 40 & 23 & 50 & 33 & 28 & & & & 11 & 30 & 37 & 63 & & 20 \\
\hline \multirow{2}{*}{$\begin{array}{l}\text { Empati } \\
\text { kurarak } \\
\text { dinleme }\end{array}$} & $\mathrm{f}$ & & & & & & 1 & 3 & 1 & 5 & & & & & 1 & & 3 & & 4 \\
\hline & $\%$ & & & & & & 8 & 30 & 11 & 7 & & & & & 10 & & 37 & & 7 \\
\hline \multirow{2}{*}{$\begin{array}{l}\text { Yaratic } \\
\text { dinleme }\end{array}$} & $\mathrm{f}$ & & & & & & & & & - & & & & & & & & & - \\
\hline & $\%$ & & & & & & & & & - & & & & & & & & & - \\
\hline \multirow{2}{*}{$\begin{array}{l}\text { Seçici } \\
\text { dinleme }\end{array}$} & $\mathrm{f}$ & & & & 3 & 3 & 4 & 1 & 2 & 13 & 2 & 3 & 2 & 2 & 4 & 1 & & & 14 \\
\hline & $\%$ & & & & 21 & 30 & 31 & 10 & 22 & 19 & 33 & 33 & 22 & 22 & 40 & 13 & & & 24 \\
\hline \multirow{2}{*}{$\begin{array}{l}\text { Eleştirel } \\
\text { dinleme }\end{array}$} & $\mathrm{f}$ & & & & & & & & 1 & 1 & & & & & & & & & - \\
\hline & $\%$ & & & & & & & & 11 & 1 & & & & & & & & & - \\
\hline \multirow{2}{*}{$\begin{array}{l}\text { Tahmin } \\
\text { ederek } \\
\text { dinleme }\end{array}$} & $\mathrm{f}$ & 5 & & 7 & 5 & 1 & 5 & 1 & & 24 & 4 & 4 & 5 & 6 & 2 & 4 & & & 25 \\
\hline & $\%$ & 83 & & 100 & 36 & 10 & 38 & 10 & & 35 & 66 & 44 & 56 & 67 & 20 & 50 & & & 42 \\
\hline \multirow{2}{*}{$\begin{array}{l}\text { Belirtilme- } \\
\text { miş }\end{array}$} & $\mathrm{f}$ & 1 & & & 1 & 2 & & & 1 & 5 & & 2 & 2 & & & & & & 4 \\
\hline & $\%$ & 17 & & & 7 & 20 & & & 11 & 7 & & 22 & 22 & & & & & & 7 \\
\hline \multirow{2}{*}{ Toplam } & $\mathrm{f}$ & 6 & - & 7 & 14 & 10 & 13 & 10 & 9 & 69 & 6 & 9 & 9 & 9 & 10 & 8 & 8 & - & 59 \\
\hline & $\%$ & 9 & & 10 & 20 & 14 & 19 & 14 & 13 & 100 & 10 & 15 & 15 & 15 & 17 & 14 & 14 & & 100 \\
\hline
\end{tabular}

Tablo 4'e göre MEB tarafından basılmış Türkçe ders kitaplarında 69, özel yayınevleri tarından basılmış Türkçe ders kitaplarındaysa 59 dinleme/izleme stratejisi tespit edilmiştir. MEB kitaplarında en fazla dinleme/izleme stratejisine yer veren ders kitabı 4. sinıf ders kitabidır ( $f=14)$. Bunu 6. sinif $(f=13), 5$. sinıf $(\mathrm{f}=10)$ ve 7 . sinıf $(\mathrm{f}=10)$ ders kitapları takip etmektedir. Özel yayınevlerine ait kitaplar içinde dinleme/izleme stratejisine en fazla yer veren ders kitabiysa 7. sinif ders kitabidir $(\mathrm{f}=10)$. Bunu 2. sinif $(\mathrm{f}=90)$, 3. sinıf $(\mathrm{f}=9)$ ve 4 . sinif ders kitapları $(\mathrm{f}=9)$ izlemektedir. Her iki yayınevine ait ders kitaplarında kullanılan dinleme/izleme stratejilerinin sınıf seviyesi açısından dağılımları dağınık bir görünüm arz etmektedir.

MEB yayınlarına ait ders kitapları içinde en fazla kullanılan dinleme/izleme stratejisi tahmin ederek dinlemedir (\%35). Bunu sirasıyla not alarak dinleme (\%28), seçici dinleme (\%19) izlemektedir. Ayrıca farklı sınıf seviyelerinde olmak üzere toplamda 5 adet dinleme/izleme metninde kullanilan strateji, belirsizdir. Özel yayınevlerine ait toplam 4 adet dinleme/izleme metninde de kullanılan strateji belirsizdir. Özel yayınevlerine ait Türkçe ders ki- 
tapları içinde en çok kullanılan dinleme/izleme stratejisi tahmin ederek dinlemedir (\%42). Ardından seçici dinleme (\%24) ve not alarak dinleme (\%20) gelmektedir. Bu bağlamda hem MEB yayınlarının hem de özel yayınevlerinin ders kitaplarında en çok kullanılan dinleme stratejilerinin aynı olduğu söylenebilir. Bu durumu gerek özel gerekse de MEB yayınevlerince hazırlanan Türkçe ders kitaplarında en çok kullanılan tahmin ederek dinleme stratejisinin her metin türüne ve amacına uyarlanabilecek kullanışlı stratejilerden biri olmasıyla izah etmek mümkündür.

Sınıf seviyeleri bakımından en sık başvurulan dinleme/izleme stratejilerine bakılırsa MEB yayınevine ait Türkçe ders kitaplarında tahmin ederek dinleme stratejisinin (\%35) en çok 3. sinıf (\%100), 6. sinıf (\%38) ve 4. sinıfta (\%36); not alarak dinleme stratejisinin (\%28) en çok 5. sinıfta (\%50); seçici dinleme stratejisininse en çok 6. sınıf (\%31) ve 3. sınıfta (\%30) kullanıldığı görülmektedir. Özel yayınevleri tarafından hazırlanmış Türkçe ders kitaplarında en çok başvurulan dinleme/izleme stratejilerine sınıf bazında bakıldığında tahmin ederek dinleme stratejisinin (\%42) en çok 4. sınıf (\%67), 1. sinıf (\%66), 3. sinıfta (\%56); seçici dinleme stratejisinin (\%24) en çok 5. sinıf (\%40), 2. sinıf (\%33) ve 1. sinıfta (\%33); not alarak dinleme stratejisininse (\%20) en çok 7. sinıf (\%63), 6. sinıf (\%37) ve 5. sinıfta (\%30) kullanıldığı dikkat çekmektedir. Tablo 4'e göre MEB yayınevine ait Türkçe ders kitaplarında katılımsız dinleme, yaratıcı dinleme gibi stratejiler kullanılmamıştır. Aynı şekilde özel yayınevlerine ait Türkçe ders kitaplarındaysa katılımlı dinleme, katılımsız dinleme, yaratıcı dinleme, eleştirel dinleme stratejilerine yer verilmemiştir. Hem MEB hem de özel yayınevlerine ait Türkçe ders kitaplarında yaratıcı dinleme stratejisine yer verilmemesi kullanılan dinleme/izleme stratejilerinin çeşitliliği açısından MEB yayınevine ait kitaplar içerisinde 8. $\sin ı f(\mathrm{f}=5), 4 \sin ı f(\mathrm{f}=4)$, 6. $\sin ı f(f=7)$ ve 7 . sinıf $(\mathrm{f}=4)$; özel yayınevlerine ait ders kitapları arasındaysa 3. $\sin 1 f(f=3), 4$. sinıf $(f=3), 5$. sinıf $(f=3), 6$. sinıf ( $(\mathrm{f}=3)$ ders kitapları öne çıkmaktadır. Diğer kitaplara göre daha az düzeyde dinleme/ izleme stratejisi kullandığ 1 tespit edilen MEB yayınevine ait kitaplar 1 . $\sin ı f(f=1)$ ve 3 . sinıf $(f=1)$; özel yayinevlerine ait olanlarsa 1 . $\sin \mathrm{f}(\mathrm{f}=2)$ ve 2 . $\sin \mathrm{f}(\mathrm{f}=2)$ ders kitaplarıdır. 
Anlama Becerisi Açısından Okuma ve Dinleme/İzleme Stratejilerinin Türkçe Ders Kitaplarındaki Yeri

Tablo 5. Okuma stratejilerinin metin türleri bakımından yayınevlerine göre dağılımı

\begin{tabular}{|c|c|c|c|c|c|c|c|c|c|}
\hline \multirow[b]{2}{*}{$\begin{array}{l}\text { Okuma Strateji- } \\
\text { leri }\end{array}$} & \multirow[b]{2}{*}{$\begin{array}{l}\mathbf{f} / \\
\%\end{array}$} & \multicolumn{2}{|c|}{ MEB Yayınları } & \multicolumn{6}{|c|}{ Özel Yayınevi } \\
\hline & & 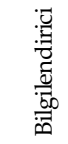 & 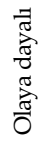 & 春 & $\frac{\text { ్ㅠㅁ }}{\text { 뭄 }}$ & 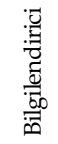 & 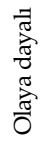 & 浔 & $\frac{\text { 츔 }}{\text { 음 }}$ \\
\hline \multirow{2}{*}{ Eleştirel okuma } & $\mathrm{f}$ & 3 & & & 3 & 1 & & & 1 \\
\hline & $\%$ & 4 & & & 2 & 1 & & & 0,4 \\
\hline \multirow{2}{*}{ Yaratıcı okuma } & $\mathrm{f}$ & & & & - & & & & - \\
\hline & $\%$ & & & & - & & & & - \\
\hline \multirow{2}{*}{$\begin{array}{l}\text { Altını } \\
\text { çizerek okuma }\end{array}$} & $\mathrm{f}$ & 5 & 3 & & 8 & 2 & 2 & 1 & 5 \\
\hline & $\%$ & 6 & 4 & & 4 & 3 & 2 & 2 & 2 \\
\hline \multirow{2}{*}{$\begin{array}{l}\text { Göz } \\
\text { atarak okuma }\end{array}$} & $\mathrm{f}$ & & & & - & & & & - \\
\hline & $\%$ & & & & - & & & & - \\
\hline \multirow{2}{*}{$\begin{array}{l}\text { Soru } \\
\text { sorarak okuma }\end{array}$} & $\mathrm{f}$ & & & & - & 4 & & & 4 \\
\hline & $\%$ & & & & - & 6 & & & 2 \\
\hline \multirow{2}{*}{$\begin{array}{l}\text { Özetleyerek } \\
\text { okuma }\end{array}$} & $\mathrm{f}$ & & 2 & & 2 & & & & - \\
\hline & $\%$ & & 3 & & 1 & & & & - \\
\hline \multirow{2}{*}{$\begin{array}{l}\text { İşaretleyerek } \\
\text { okuma }\end{array}$} & $\mathrm{f}$ & 1 & & & 1 & 1 & 1 & & 2 \\
\hline & $\%$ & 1 & & & 0,5 & 1 & 1 & & 1 \\
\hline \multirow{2}{*}{ Sesli okuma } & $\mathrm{f}$ & 35 & 25 & 16 & 76 & 27 & 21 & 34 & 82 \\
\hline & $\%$ & 43 & 36 & 42 & 40 & 36 & 25 & 59 & 38 \\
\hline \multirow{2}{*}{ Sessiz okuma } & $\mathrm{f}$ & 8 & 7 & & 15 & 18 & 15 & 1 & 34 \\
\hline & $\%$ & 10 & 10 & & 8 & 24 & 18 & 2 & 16 \\
\hline \multirow{2}{*}{$\begin{array}{l}\text { Tahmin } \\
\text { ederek okuma }\end{array}$} & $\mathrm{f}$ & 7 & 7 & & 14 & 6 & 15 & 2 & 23 \\
\hline & $\%$ & 9 & 10 & & 7 & 8 & 18 & 3 & 11 \\
\hline \multirow{2}{*}{ Ezberleme } & $\mathrm{f}$ & & & 1 & 1 & & & 2 & 2 \\
\hline & $\%$ & & & 3 & 0,5 & & & 3 & 1 \\
\hline \multirow{2}{*}{ Okuma tiyatrosu } & $\mathrm{f}$ & & 2 & & 2 & & 9 & & 9 \\
\hline & $\%$ & & 3 & & 1 & & 11 & & 4 \\
\hline \multirow{2}{*}{$\begin{array}{l}\text { Tartışarak } \\
\text { okuma }\end{array}$} & $\mathrm{f}$ & & & & & 2 & & & 2 \\
\hline & $\%$ & & & & - & 3 & & & 1 \\
\hline \multirow{2}{*}{ Hizlı okuma } & $\mathrm{f}$ & & & & - & 1 & & & 1 \\
\hline & $\%$ & & & & - & 1 & & & 0,4 \\
\hline \multirow{2}{*}{$\begin{array}{l}\text { Paylaşarak } \\
\text { okuma }\end{array}$} & $\mathrm{f}$ & & & & - & & 2 & 1 & 3 \\
\hline & $\%$ & & & & - & & 2 & 2 & 1 \\
\hline \multirow{2}{*}{$\begin{array}{l}\text { Not } \\
\text { alarak okuma }\end{array}$} & $\mathrm{f}$ & 6 & 1 & & 7 & 4 & 3 & & 7 \\
\hline & $\%$ & 7 & 1 & & 4 & 6 & 4 & & 3 \\
\hline \multirow{2}{*}{ Görsel okuma } & $\mathrm{f}$ & 3 & 8 & 4 & 15 & 2 & 3 & 2 & 7 \\
\hline & $\%$ & 4 & 12 & 10 & 8 & 3 & 4 & 3 & 3 \\
\hline C̈̈̈l & $\mathrm{f}$ & & & 1 & 1 & & & 1 & 1 \\
\hline soz Korosu & $\%$ & & & 3 & 0,5 & & & 2 & 0,4 \\
\hline & $\mathrm{f}$ & 3 & 3 & & 6 & 5 & 1 & 7 & 13 \\
\hline Seçici okuma & $\%$ & 4 & 4 & & 3 & 7 & 1 & 12 & 6 \\
\hline Yankılayıcı & $\mathrm{f}$ & & & 1 & 1 & & & & \\
\hline okuma & $\%$ & & & 3 & 0,5 & & & & - \\
\hline Belirtilmemic & $\mathrm{f}$ & 10 & 11 & 15 & 36 & 1 & 12 & 7 & 20 \\
\hline Belırtılmemış & $\%$ & 12 & 16 & 39 & 19 & 1 & 14 & 12 & 9 \\
\hline TOPI AM & $\mathrm{f}$ & 81 & 69 & 38 & 188 & 74 & 84 & 58 & 216 \\
\hline TOPLAM & $\%$ & 43 & 36 & 20 & 100 & 34 & 38 & 26 & 100 \\
\hline
\end{tabular}


Tablo 5'e göre MEB tarafından basılmış Türkçe ders kitaplarında yer alan okuma metinlerine ilişkin olarak bilgilendirici metinlerde $\% 12$, olaya dayalı metinlerde $\% 16$, şiir türü metinlerdeyse $\% 39$ oranında okuma stratejisinin belirtilmediği görülmektedir. Bu sayıları toplamın dışında tutarsak MEB tarafından hazırlanmış ders kitaplarında kullanılan okuma stratejilerinin 71 'i bilgilendirici metinlerde, 58'i olaya dayalı metinlerde, 23'ü şïr türü metinlerde kullanılmıştır. Aynı şekilde özel yayınevlerince hazırlanan Türkçe ders kitaplarındaki okuma stratejileri, $\% 1$ oranında bilgilendirici metinlerde, $\% 14$ olaya dayalı metinlerde, \%12 şiir türü metinlerde belirtilmemiştir. Bu sayıları toplamın dışında tutarsak özel yayınevleri tarafından hazırlanmış ders kitaplarında kullanılan okuma stratejilerinin 73'ü bilgilendirici metinlerde, 72'si olaya dayalı metinlerde, 51'i şiir türü metinlerde kullanılmıştır.

MEB yayınlarına ait ders kitapları içinde bilgilendirici metinler başlı̆̆ında toplam 9 okuma stratejisi kullanılmıştır. Bunlar arasında en çok kullanılan okuma stratejileri sesli okuma (\%43), sessiz okuma (\%10) ve tahmin ederek okumadır (\%9). Olaya dayalı metinler başlığı altında toplam 9 adet strateji kullanılmış olup bunlar içinde en çok sesli okuma (\%36), görsel okuma (\%12), sessiz okuma (\%10), tahmin ederek okuma (\%10) kullanılmıştır. Toplam 5 adet okuma stratejisinin kullanıldığ 1 şiir türü metinlerdeyse en çok sesli okuma (\%42) ve görsel okuma (\%10) stratejileri kullanılmıştır. Özel yayınevleri tarafından hazırlanan Türkçe ders kitaplarına baktığımızda bilgilendirici metinler başlığında toplam 12 okuma stratejisi kullanılmıştır. Bunlar arasında en çok kullanılan okuma stratejileri sesli okuma (\%36), sessiz okuma (\%27), tahmin ederek okuma (\%8) ve seçici okumadır (\%7). Olaya dayalı metinler başlığında toplam 10 adet okuma stratejisi bulunmaktadır. Bu stratejiler arasinda en sik kullanılanlarsa sesli okuma (\%25), sessiz okuma (\%18), tahmin ederek okuma (\%18) ve okuma tiyatrosudur (\%11). Toplam 9 adet okuma stratejisinin kullanıldığı şiir türü metinlerde en çok sesli okuma (\%59) ve seçici okuma (\%12) stratejileri kullanılmıştır. 
Tablo 6. Dinleme/İzleme Stratejilerinin Metin Türleri Bakımından Yayınevlerine Göre Da$\underline{\text { ğılımı }}$

\begin{tabular}{|c|c|c|c|c|c|c|c|c|c|}
\hline \multirow[b]{2}{*}{$\begin{array}{l}\text { Dinleme/İzleme } \\
\text { Stratejileri }\end{array}$} & \multirow[b]{2}{*}{$\begin{array}{l}\text { f/ } \\
\%\end{array}$} & \multicolumn{2}{|c|}{ MEB Yayınları } & \multicolumn{6}{|c|}{ Özel Yayınevi } \\
\hline & & $\begin{array}{l}: \overrightarrow{0} \\
: \vec{G} \\
\overrightarrow{0} \\
\frac{0}{00} \\
\overrightarrow{00}\end{array}$ & 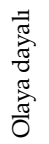 & : & 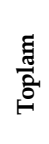 & 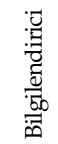 & 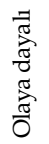 & 奉 & 竎 \\
\hline \multirow{2}{*}{ Katılımlı dinleme } & $\mathrm{f}$ & 1 & 1 & - & 2 & & & & - \\
\hline & $\%$ & 3 & 4 & & 3 & & & & - \\
\hline \multirow{2}{*}{ Katılımsız dinleme } & $\mathrm{f}$ & & & & - & & & & - \\
\hline & $\%$ & & & & - & & & & - \\
\hline \multirow{2}{*}{ Not alarak dinleme } & $\mathrm{f}$ & 13 & 4 & 2 & 19 & 8 & 4 & - & 12 \\
\hline & $\%$ & 41 & 14 & 18 & 28 & 40 & 16 & & 20 \\
\hline \multirow{2}{*}{$\begin{array}{l}\text { Empati } \\
\text { kurarak dinleme }\end{array}$} & $\mathrm{f}$ & 3 & 2 & & 5 & 2 & 2 & & 4 \\
\hline & $\%$ & 10 & 7 & & 7 & 10 & 8 & & 7 \\
\hline \multirow{2}{*}{ Yaratıcı dinleme } & $\mathrm{f}$ & & & & - & & & & - \\
\hline & $\%$ & & & & - & & & & - \\
\hline \multirow{2}{*}{ Seçici dinleme } & $\mathrm{f}$ & 3 & 7 & 3 & 13 & 4 & 4 & 6 & 14 \\
\hline & $\%$ & 10 & 26 & 27 & 19 & 20 & 16 & 40 & 24 \\
\hline \multirow{2}{*}{ Eleştirel dinleme } & $\mathrm{f}$ & 1 & & & 1 & & & & - \\
\hline & $\%$ & 3 & & & 1 & & & & - \\
\hline \multirow{2}{*}{$\begin{array}{l}\text { Tahmin } \\
\text { ederek dinleme }\end{array}$} & $\mathrm{f}$ & 7 & 12 & 5 & 24 & 5 & 13 & 7 & 25 \\
\hline & $\%$ & 22 & 44 & 45 & 35 & 25 & 54 & 46 & 42 \\
\hline \multirow{2}{*}{ Belirtilmemiş } & $\mathrm{f}$ & 3 & 1 & 1 & 5 & 1 & 1 & 2 & 4 \\
\hline & $\%$ & 10 & 4 & 9 & 7 & 5 & 4 & 13 & 7 \\
\hline \multirow{2}{*}{ Toplam } & $f$ & 31 & 27 & 11 & 69 & 20 & 24 & 15 & 59 \\
\hline & $\%$ & 44 & 39 & 15 & 100 & 34 & 41 & 25 & 100 \\
\hline
\end{tabular}

Tablo 6'ya göre MEB tarafindan basılmış Türkçe ders kitaplarında yer alan dinleme/izleme metinlerine ilişkin olarak bilgilendirici metinlerde $\% 10$, olaya dayalı metinlerde $\% 4$, şiir türü metinlerdeyse $\% 9$ oranında dinleme/izleme stratejisinin belirtilmediği görülmektedir. Bu sayıları toplamın dışında tutarsak MEB tarafından hazırlanmış ders kitaplarında kullanılan dinleme/izleme stratejilerinin $28^{\prime}$ i bilgilendirici metinlerde, 26 'sı olaya dayalı metinlerde, $10^{\prime} \mathrm{u}$ şiir türü metinlerde kullanılmıştır. Aynı şekilde özel yayınevlerince hazırlanan Türkçe ders kitaplarındaki dinleme/izleme stratejileri \%1 oranında bilgilendirici metinlerde, \%14 olaya dayalı metinlerde, \%12 şiir türü metinlerde belirtilmemiştir. Bu sayıları toplamın dışında tutarsak özel yayınevleri tarafından hazırlanmış ders kitaplarında kullanılan dinleme/izleme stratejilerinin $19^{\prime}$ u bilgilendirici metinlerde, 23'ü olaya dayalı metinlerde, 13'ü şiir türü metinlerde kullanılmıştır.

MEB yayınlarına ait ders kitapları içinde bilgilendirici metinler başlığında toplam 5 adet dinleme/izleme stratejisi kullanılmıştır. Bunlar arasında en çok 
kullanılan dinleme/izleme stratejileri not alarak dinleme (\%41), tahmin ederek dinleme (\%22), empati kurarak dinleme (\%10) ve seçici dinlemedir (\%10). Olaya dayalı metinler başlı̆ğ altında toplam 5 adet strateji kullanılmış olup bunlar içinde en çok tahmin ederek dinleme (\% 44), seçici dinleme (\%26) ve not alarak dinleme (\%14) stratejileri tercih edilmiştir. Toplam 3 adet okuma stratejisinin kullanıldığ1 şiir türü metinlerdeyse en çok sesli tahmin ederek dinleme stratejisi (\%45) kullanılmıştır.

Özel yayınevleri tarafından hazırlanan Türkçe ders kitaplarına baktığ1mızda bilgilendirici metinler başlı̆̆ında toplam 4 dinleme/izleme stratejisi kullanılmıştır. Bunlar arasında en çok kullanılan dinleme/izleme stratejileri not alarak dinleme (\%40), tahmin ederek dinleme (\%25) ve seçici dinlemedir (\%20). Olaya dayalı metinler başlığında da toplam 4 adet dinleme/izleme stratejisi bulunmaktadır. Bu stratejiler arasında en sık kullanılanlar tahmin ederek dinleme (\%54), not alarak dinleme (\%16) ve seçici dinlemedir (\%16). Toplam 2 adet okuma stratejisinin kullanıldığı şiir türü metinlerde tahmin ederek dinleme (\%46) ve seçici dinleme (\%40) stratejileri kullanılmıştır.

\section{Tartışma ve Sonuç}

Araştırma sonuçlarına göre okuma stratejilerinin bazılarının çok bazılarınınsa daha az kullanıldığı tespit edilmiştir. Sınıf seviyeleri açısından okuma stratejilerinin kullanılma sıklıklarında belli bir düzen olmadığı görülmüsstür. Kitap yazarları açısından kullanılan yöntem, teknik ve stratejilerin kullanımında bir denge gözetilmesi gerekse de bununla ilgili öğretim programında bağlayıcı bir ifade bulunmamaktadır. Bu bulgular, Topuzkanamış'ın (2010) kitap yazarlarının okuma stratejilerine uygun şekilde etkinlik hazırlamamalarının normal karşılanması gerektiği yönündeki görüşleriyle örtüşmektedir.

MEB yayınevinden çıkan kitaplar arasında, kullanılan okuma stratejilerinin çeşitliliği açısından 7. sınıf ( $\mathrm{f}=10$ ), özel yayınevlerine ait ders kitapları arasindaysa 5. $\sin ı f(f=13)$ ders kitapları öne çımaktadır. Kullanılan okuma stratejileri bakımından daha az çeşitliliğe sahip olan kitaplar hem MEB yayınevinde hem de özel yayınevlerinde 1 . sınıf Türkçe ders kitapları olmuştur. Oysaki ana dil eğitiminde öğrencilere okutulan ders kitaplarında yer alan temel beceri alanlarına ilişkin farklı stratejilerin kullanılması oldukça önemlidir. 
Öğrenciler, farkında olmadan elde ettikleri becerileri okuma stratejileri yardımıyla geliştirebilmekte ve yeni beceriler elde etme imkânına sahip olmaktadirlar (Pang, 2008).

Topuzkanamış (2010) okuma stratejileri üzerine yaptığ çalışmasında bazı okuma etkinliklerinin amacının ve öğrencinin söz konusu etkinlikle ne kazanacağının belirtilmediği, bu konuda öğretmenin açıklayıcı ve destekleyici rolünün olduğundan bahsetmektedir. Benzer şekilde bu araştırma sonuçlarına göre MEB yayınevine ait 36, özel yayınevlerine ait 20 tane okuma metninde okuma stratejisi belirtilmemiştir. Söz konusu durum, başta birinci sınfflar olmak üzere muhtelif sınıf seviyelerinde görülmektedir. Bu konuyla ilgili okuma stratejisini, amaç ve hedef kazanımın belirlenmesi dersin öğretmeninin sorumluluğuna bırakılmıştır. Kimi okuma stratejilerine doğrudan veya dolaylı olarak yer verilmemiş olması, söz konusu ders kitabında bu okuma stratejilerinin kullanılamayacağı şeklinde yorumlanmamalıdır. Nitekim bu araştırma sonucunda görülmüştür ki MEB yayınevine ait 36, özel yayınevlerine ait 20 metinde herhangi bir okuma stratejisine atıfta bulunulmamış; ilgili okuma metnine ait stratejinin belirlenmesi ders öğretmeninin inisiyatifine b1rakılmıştır. $\mathrm{Bu}$ araştırma ve benzeri araştırmalar ortaya koymaktadır ki Türkçe dersi öğretmenleri, ders kitapları üzerine yapılan akademik çalışmaları da inceleyerek ders işleme sürecini planlaması gerekmektedir. Gerek özel yayınevleri gerekse de MEB yayınevi tarafından hazırlanmış Türkçe ders kitabında kullanıldığı tespit edilen okuma stratejilerinin sayıca özel yayınevleri lehine bir üstünlüğü olsa da her iki grupta da Türkçe ders kitaplarında kullanılan stratejiler, oranlar açısından benzerdir.

Okuma stratejilerinin metin türleri açısından MEB yayınevine göre bilgilendirici metinlerde, özel yayınevlerinde ise olaya dayalı metinlerde daha fazla olduğu tespit edilmiştir. Şiir türü metinlerde kullanılan okuma stratejilerinin hem MEB kitaplarında hem de özel yayınevlerinin hazırladığı Türkçe ders kitaplarında daha az olduğu görülmektedir. Bunun şïr türünün ders kitaplarında daha az tercih edilmesiyle ilgili bir durum olduğunu söylemek mümkündür. Bu durum Bayram ve Kara'nın (2020) Türkçe ders kitaplarında kullanılan metin türleri üzerine yaptığı çalışmasında da ortaya konmuştur. Her iki yayınevi açısından da metin türlerine göre gerek bilgilendirici gerek olaya dayalı metin gerekse de şiir türü metin olsun en fazla kullanılan okuma stratejisi sesli okuma olmuştur. Bu sonucun tesadüfi olmadığını söylemek 
mümkündür. Çünkü sesli okuma stratejisi ders öğretmenine dönüt ve düzeltme verebilmesi açısından en uygun yöntemdir. Çifci'ye (2000) göre sesli okuma stratejisi; öğrencinin okuma becerisinin gelişimi, doğru ve güzel telaffuz alışkanlığ 1 edinme, dinleyicilere bilgi aktarma, standart konuşma dili becerisi edinme, anlamanın gerçekleşmesi, sessiz okuma çalışmalarına zemin hazırlama ve öğrencilerin sosyalleşmesi gibi farklı yönlerden üstünleri bulunmaktadır.

Hem MEB hem de özel yayınevleri tarafından hazırlanmış Türkçe ders kitaplarında sessiz okuma stratejisinin en fazla kullanılan stratejiler arasında yer alması da oldukça manidardır. Günlük hayatta da en çok kullandığımız okuma stratejisi olarak sessiz okuma, okunanların daha hızlı ve doğru anlaşılması noktasında önem taşımaktadır. Nitekim Akar'a (2009) göre beyin ile göz arasındaki koordinasyonun sağlanmasında araya farklı bir organın girmeyişi, görülenlerin beyne aracısız şekilde doğrudan iletilmesi ve anlamlandırılması, sessiz okumayı anlama üzerinde daha etkili kılmakta, anlama oranını artırma bakımından diğer okuma stratejilerinden ayrı bir yere koymaktadir.

Araştırma sonucuna göre hem MEB hem de özel yayınevleri tarafından hazırlanmış Türkçe ders kitaplarında kullanılan dinleme/izleme stratejilerinin sınıf düzeylerine göre ders kitaplarında kullanılmasında sistemli bir artış veya azalma söz konusu değildir. Ancak hem MEB Yayınlarının hem de özel yayınevlerinin hazırladığı Türkçe ders kitaplarında en çok kullanılan ilk üç stratejinin (tahmin ederek, not alarak ve seçici dinleme) aynı olduğu sonucuna ulaşılmıştır. Özellikle en çok kullanılan tahmin ederek dinleme stratejisinin, öğrencilerin dinleme/izleme faaliyetlerinde sorgulama, eleştirme, çıkarımda bulunma, analiz etme, eleştirme ve değerlendirme gibi üst düzey zihinsel işlemler yapmasına elverişli bir yöntem olması bakımından sık kullanımının tercih edilmesi şaşırtıcı değildir. Her iki yayınevi grubu için de en sık tercih edilen dinleme stratejilerinden olan not alarak dinleme, bilginin kalıc1lığını sağlama, hafızada tutmayı kolaylaştırması bakımından kullanılan bir stratejidir. İncelemeye esas ders kitaplarında kullanılan dinleme/izleme stratejilerinin metin türleri bakımından dağılımına baktığımızda, MEB yayınlarında bilgilendirici metinlerde, özel yayınevlerindeyse olaya dayalı metinlerde daha fazla dinleme/izleme stratejisinin kullanıldığını görmekteyiz. Yine şiir türü metin sayısına bağlı olarak kullanılan dinleme/izleme stratejisi sayılarının az olduğu görülmektedir. 
MEB yayınlarına ait ders kitaplarındaki bilgilendirici metinlerde daha çok not alarak dinleme, olaya dayalı ve şiir türü metinlerde ise tahmin ederek dinleme daha yoğun kullanılmıştır. Özel yayınevlerine ait ders kitaplarında ise bilgilendirici metinlerde not alarak dinleme, olaya dayalı ve şiir türü metinlerdeyse tahmin ederek dinleme stratejileri daha yoğun şekilde kullanılmiştır.

\section{Öneriler}

Ders kitaplarında bazı stratejilerinin daha çok kullanılmasından ziyade farklı stratejilere yer verilmesi gerektiği önerilebilir. Bunun için ders kitabı yazarlarının kitaplarını yazarken programın ön gördüğü şekilde farklı stratejileri işe koşmaları tavsiye edilebilir. Bunun yanı sıra öğretmenlerin de uygulama esnasında farklı stratejileri işe koşarak ders işlemesi öğrencilerin akademik başarılarını ve motivasyonlarını artıracaktır. Yine programın ön gördüğü şekilde öğrencilerin yaratıcı ve eleştirel düşünme becerilerini geliştirmek için eleştirel ve yaratıcı okuma/dinleme stratejilerine ders kitaplarında daha fazla yer verilebilir. 


\title{
EXTENDED ABSTRACT
}

\section{Reading and Listening/Viewing Strategies in Terms of Comprehension Skills in Turkish Language Textbooks}

\author{
Bora Bayram - Elif Aktaş \\ Alanya Alaaddin Keykubat Üniversitesi
}

Teaching Turkish Language aims to improve the individual's comprehension and narrative skills from basic education to higher education. In this direction, the 2019 Turkish Language Curriculum (TLC), which is an important guide, is structured in a way that will enable students to acquire language skills and mental skills related to listening / watching, speaking, reading and writing, which they can use lifelong. Reading, which is one of the comprehension skills, is the learning area that contributes the most to the mental development of the student, and it is among the general objectives of students to improve their reading skills and gain reading habit in primary education. Another component of comprehension skills is listening, which forms the basis for other learning areas. Listening / watching is one of the basic language skills of Turkish language and begins to be acquired in the womb. As a matter of fact, children start the language learning process with listening. Statements such as "Applies reading strategies" and "Implements listening / watching strategies" are among the acquisitions related to reading and listening / watching skills included in the curriculum at every grade level, and it also requires the use of some strategies in developing understanding skills.

This research sets out to determine the distribution of reading and listening/ watching strategies in the Turkish language coursebooks of $1^{\text {st_ }} 8^{\text {th }}$ grades prepared on the basis of the 2019 Turkish Language Curriculum based on a skill-based understanding, in terms of grade levels, text types and publishers. In line with this purpose, reading and listening/ watching strategies in 14 Turkish textbooks belonging to MoNE and private publishing houses were determined and analyzed by calculating frequency and percentage values. Within the scope of the research, answers to the following questions were sought: 
1. What is the distribution of reading strategies in $1^{\text {st }} 8^{\text {th }}$ grade Turkish textbooks by grade levels?

2. What is the distribution of reading strategies in $1^{\text {st }}-8^{\text {th }}$ grade Turkish textbooks by publishing houses in terms of text type?

3. What is the distribution of listening / watching strategies in $1^{\text {st }-8^{\text {th }}}$ grade Turkish textbooks in terms of grade levels?

4. What is the distribution of listening / watching strategies in $1^{\text {st_- }} 8^{\text {th }}$ grade Turkish textbooks by publishing houses in terms of text type?

This study was designed according to the qualitative research method and document analysis was used as data collection tool. The data obtained as a result of the research were analyzed using the descriptive analysis technique, which means transforming the raw data into a form that the reader can understand and use when needed.

According to the results of the research, it was seen that there is no certain order in the frequency of using reading strategies in terms of grade levels. Although a balance should be observed in the use of methods, techniques and strategies used by the authors of the book, there is no binding expression in the curriculum about this.

In terms of the variety of reading strategies used, $7^{\text {th }}$ class $(f=10)$ textbooks stand out among the books of the MoNE publishing house, and $5^{\text {th }}$ class $(\mathrm{f}=$ 13) textbooks among the textbooks of private publishing houses. The books that have less variety in terms of the reading strategies used have been $1^{\text {st }}$ grade Turkish textbooks in both the MoNE publishing house and private publishing houses. However, it is very important to use different strategies regarding the basic skill areas included in the textbooks that are taught to students in mother tongue education. Similarly, according to the results of this research, the reading strategy is not specified in 36 reading texts belonging to MoNE publishing houses and 20 reading texts belonging to private publishing houses. The aforementioned situation is observed in various grade levels, especially in the first grade. Determining the reading strategy, purpose and target acquisition on this subject is left to the responsibility of the teacher of the course.

Although the reading strategies used in Turkish language textbooks prepared by both private publishing houses and the MoNE have an advantage in favor of private publishing houses in terms of quantity, the strategies used in Turkish language textbooks in both groups are similar in terms of rates. 
In terms of text types, reading strategies were found to be more in informative texts than in the MoNE publishing house, and more in case-based texts in private publishing houses. It is seen that the reading strategies used in poetry type texts are less in both MoNE textbooks and Turkish language textbooks prepared by private publishing houses.

For both publishers, reading aloud was the most used reading strategy, whether informative, event-based text or poetry text, according to text types. It is possible to say that this result is not accidental. Because reading aloud strategy is the most appropriate method in terms of giving feedback and correction to the course teacher.

It is also very significant that the silent reading strategy is among the most used strategies in Turkish language textbooks prepared by both the MoNE and private publishing houses. Silent reading, as the reading strategy we use most in daily life, is important for faster and more accurate understanding of what is read.

According to the results of the research, there is no systematic increase or decrease in the use of listening / watching strategies in Turkish language textbooks prepared by both the MoNE and private publishing houses according to grade levels.

However, it was concluded that the first three strategies (listening by guessing, taking notes and selective listening) are the same in Turkish language textbooks prepared by both MoNE and private publishing houses.

Listening by taking note, which is one of the most preferred listening strategies for both publisher groups, is a strategy used in terms of ensuring the permanence of information and making it easier to keep in memory. Listening by taking notes was used more in informative texts in the textbooks of MoNE and listening by guessing was used more intensively in case-based and poetry-type texts.

It can be suggested that different strategies should be included in the textbooks rather than using some strategies more. For this, textbook authors may be advised to use different strategies as the program predicts while writing their books. 


\section{Kaynakça / References}

Akar, M. (2009). Sesli ve sessiz okumanın anlamaya etkisi üzerine bir araştırma. Yayımlanmamış yüksek lisans tezi. Afyon Kocatepe Üniversitesi Sosyal Bilimler Enstitüsü, Afyonkarahisar.

Aktaş, Ş. ve Gündüz, O. (2004). Yazılı ve sözlü anlatım-kompozisyon sanatı. Ankara: Akçağ Yayınları.

Bayram, B. ve Kara, K. (2020). Examination of texts in secondary school Turkish language textbooks in terms of genre. International Journal of Eurasian Education and Culture, 5(8), 254- 269.

Çifci, M. (2000). Sesli okuma. Bilge, 24, 178-184.

Doğan, Y. (2013). Dinleme eğitimi: Kuram, uygulama, ölçme ve değerlendirme. A. Güzel ve H. Karatay (Ed.) Türkçeöğretimi el kitabı içinde. (s. 151-178). Ankara: PegemA Yayınları.

Ergin, A. (2014). Eğitimde etkili iletişim. Ankara: Anı Yayıncllık.

Güneş, F. (2014). Türkçe öğretimi yaklaşımlar ve modeller. Ankara: PegemA Yayınları.

Kurudayıoğlu, M. ve Kiraz, B. (2020). Hazırlıksız konuşma stratejileri. RumeliDE Dil ve Edebiyat Araştırmalan Dergisi, 20, 167-189.

MEB. (2005) İlköğretim Türkçe dersi (6, 7, 8. sımılar) öğretim programı. Ankara: MEB yayınları.

MEB (2019). Türkçe dersi öğretim programı (1-8. sımıflar). Ankara: MEB yayınları.

Melanlıŏ̆lu, D. (2013). Ortaokul öğrencileri için dinleme kaygisı ölçeğinin geçerlik ve güvenirlik çalışması. Adıyaman Üniversitesi Sosyal Bilimler Enstitüsü Dergisi, 11 (6), 851-876.

Merriam, S. B. (2013). Nitel araştırma desen ve uygulama için bir rehber. (S. Turan, Çev. Ed.) Ankara: Nobel.

Miles, M, B. ve Huberman, A. M. (1994). Qualitative data analysis: An expanded sourcebook. Thousand Oaks, CA: Sage.

Pang, J. (2008). Research on good and poor reader characteristics: 1mplications for 12 reading research in China. Reading in a Foreign Language, 20(1), 1-18.

Patton, M. Q. (2014). Nitel araştırma ve değerlendirme yöntemleri (Çev. Ed. Mesut Bütün ve Selçuk Beşir Demir) Ankara: PegemA Yayınları.

Topuzkanamış, A. (2010). Öğretmen adaylarının okuduğunu anlama ve okuma stratejilerini kullanma düzeyleri. Türklük Bilimi Araştırmalar, 27, 655-677.

Ülper, H. ve Yağmur, K. (2016). Doğru ve akıcı sessiz sözcük okuma testinin geliştirilmesi. İköğretim Online, 15 (2), 581-593.

Yalçın, A. (2002). Türkçe öğretim yöntemleri yeni yaklaşımlar. Ankara: Akçağ Yayınları. 
Yıldırım, A. ve Şimşek, H. (2016). Sosyal bilimlerde nitel araştırma. Ankara: Seçkin Yayinları.

\section{Kaynakça Bilgisi / Citation Information}

Bayram, B. ve Aktaş, E. (2021). Anlama becerisi açısından okuma ve dinleme/izleme stratejilerinin Türkçe ders kitaplarındaki yeri. OPUSUluslararası Toplum Araştırmaları Dergisi, 17(35), 1823-1848. DOI: 10.26466/opus.814783 